\title{
Microbial Biofilm of Plastic in Tropical Marine Environment and their Potential for Bioremediation of Plastic Waste
}

\author{
Nur Fitriah Afianti ${ }^{1 *}$, Arief Rachman', Ariani Hatmanti', \\ Deny Yogaswara', Milani Anggiani', Nurul Fitriya' ${ }^{1}$, Yeti Darmayati' \\ 1 Research Center for Oceanography, National Research and Innovation Agency, East Ancol, North Jakarta, \\ 14430, Jakarta, Indonesia \\ * Corresponding author's email: nurfitriahafianti@gmail.com
}

\begin{abstract}
Plastic debris has become a global problem due to its widespread distribution and accumulation in the marine environment. Indigenous bacteria in the marine environment are able to quickly contaminate plastic surface and assemble to form successional plastisphere-specific bacterial. The formation of microbial biofilms on the plastic surface can indirectly initiate the degradation of plastic polymers. The environmental conditions of the tropical region make the growth of microbial biofilms become faster. However, the study on the biodiversity of microorganisms in marine plastic debris is limited to the northern hemisphere, which includes subtropical and temperate regions. This review provides current studies of biodiversity and community structure of plastisphere in tropical environments, including bacteria and microalgae, and their potential to degrade the plastic polymer. A systematic literature search has been conducted using Scopus with different combinations of keywords. In addition, Google Scholar databases were also used to find more studies on some specific topics, including plastic degrading organisms. The climate-associated areas have been grouped according to the latitude of the study site into tropical, subtropical, and temperate latitudes. The microorganisms analyzed in this review are only bacteria, actinobacteria, and microalgae.
\end{abstract}

Keywords: biofilm, microorganism, plastic debris, tropical, marine environment, biodegradation.

\section{INTRODUCTION}

In modern society, plastic debris, both macro and micro-plastic, is extensively spread and accumulated in the marine environment and has become a global concern (Barnes et al., 2009; Van Cauwenberghe et al., 2015). Cosmetic microbeads, synthetic fibers from clothes, and many other products are micro-form fragments that directly propagate microplastics in the environment (Hwang et al., 2020). In 2016, more than 300 million metric tons of plastics had been produced including waste generation, and it has significantly risen worldwide (Geyer et al., 2017). In the environment, plastic debris degrades down to microplastic which high potentially enters the food chain directly and contaminates it through the degradation of chemical compounds (F. Galgani et al., 2015; Walther et al., 2018). In Indonesia, approximately $0.52 \mathrm{~kg}$ of plastic waste was generated by each person per year, and more than $80 \%$ of that total failed to be managed. Plastic debris has an $11 \%$ proportion of the total, whilst the well-managed plastic waste corresponds to about 10\% (Jambeck et al., 2015). Along $50 \mathrm{~km}$ of coastline with more than $180 \mathrm{mil}-$ lion inhabitants, approximately 5.4 million metric tons of plastic debris was generated, of which unmanaged waste is about $60 \%$; consequently, more than 1 million metric tons ultimately became marine debris (Syakti et al., 2017).

It was widely recognized that plastic debris poses a risk to marine life and human health (Iñiguez et al., 2017). Therefore, this issue has been included in national and international policies and legislation such as stated in SDGs 14 by United Nation-related life underwaters the aims to "by 2025, prevent and significantly reduce marine pollution of all kinds, particularly 
from land-based activities, including marine debris and nutrient pollution" (Zafeiridou et al., 2018). In the marine environment, plastic will break down into smaller microplastic fragments (less than $5 \mathrm{~mm}$ in diameter) due to physical and chemical processes such as ultraviolet radiation, oxidation, and mechanical forces (Galgani et al., 2018). Microplastics are ubiquitous and ingested by an extensive range of organisms due to their sizes, possibly endangering the ecosystem and public health (Maes et al., 2017).

When plastic debris accumulates in the marine environment, it will serve as a new habitat for various microorganisms. It provides a durable substrate that can be colonized by microorganisms and supports the growth of microbial biofilms. The ecosystem that has evolved to live in plastic environments is known as the plastisphere. Plastisphere is formed by the association of microorganisms with organic and inorganic substances. Indigenous bacteria in the marine environment able to quickly contaminate microplastics and assemble successional plastisphere-specific bacteria (Galgani et al., 2018). The film layer formed on plastic debris can affect the surface of the material properties and influence the colonizing microorganisms, which begin when microbes first attach to the plastic debris substrate (Rummel et al., 2017). After forming the aforementioned, an adhesion of other microorganisms can be provided by first coating. Extracellular polymeric substances (EPS) produced by microorganisms will facilitate cell adhesion to surfaces, bind other organic compounds in the environment, facilitate the metabolism of microorganisms using their extracellular enzymes and provide physical and mechanical stability (Flemming \& Wingender, 2010; L. Galgani et al., 2018). It forms a more complex biofilm (Lobelle \& Cunliffe, 2011). In addition, microalgae such as Diatomae, Cyanobacteria, and Coccolithophores groups are the fastest and earliest microbial groups to attach and form colonies on plastic substrates (Casabianca et al., 2019; Eich et al., 2015).

The microorganisms colonizing plastics were co-influenced by multiple factors, such as environmental factors, including nutrient and exposure duration, polymer types, biogeographical, and seasonal variability exposure (AmaralZettler et al., 2015; Jiang et al., 2018; McCormick et al., 2014; Oberbeckmann et al., 2018). Their research showed that geographical location has a more significant influence on the formation of microbial biofilms. Microbial biofilm formation is faster in tropical waters than in subtropical waters (Schlundt et al., 2020). It was known that the tropical region has the greatest level of biodiversity. Understanding the biodiversity of indigenous microorganisms attached to the plastic in the tropical region will certainly be a useful database for the development of several things, including the efforts to overcome the massive plastic pollution. However, the number of studies in tropical regions is lesser than in other regions. The study on the biodiversity of microorganisms in marine plastic debris is limited to the northern hemisphere, including subtropical and temperate areas (Roager \& Sonnenschein, 2019). In this review, the current status about the studies of biodiversity and community structure of plastisphere in a tropical environment, including bacteria and microalgae, and their potential to degrade plastic polymer, was provided.

\section{METHODS}

The literature research was performed using Scopus with different combinations of the following keywords: plastic, macroplastic, microplastic, microorganism, bacteria, actinobacteria, plankton, plastisphere, biofilm, biofouling, degradation, marine, ocean, and coastal. In addition, the Google Scholar databases were also used to find more studies on some specific topics, including plasticdegrading organisms. The literature research was concluded on September 17th, 2021. The studies published after this date are not included in the reference list. Review articles were excluded and only research studies were included. Duplicate articles generated due to different keyword combinations were removed. The climate-associated areas were grouped according to the latitude of the study site into tropical $\left(0-23.5^{\circ} \mathrm{N}\right.$ or $\left.\mathrm{S}\right)$, subtropical (23.5$40^{\circ} \mathrm{N}$ or $\left.\mathrm{S}\right)$, and temperate latitudes $\left(>40^{\circ} \mathrm{N}\right.$ or $\left.\mathrm{S}\right)$. The organisms analyzed in this review are only bacteria, actinobacteria and microalgae, whereas fungi are not included. Furthermore, the articles that contain the tropical region were analyzed.

\section{PLASTISPHERE}

Plastic will become a new habitat for microorganisms, known as plastisphere (Zettler et al., 2013). The plastic in marine waters will be exposed to UV radiation, heat, oxidation, 
biodegradation, and mechanical disruption. This process causes the plastic to be cut into smaller sizes, either macro, micro, or even nanoplastic. Due to the air and ocean current conditions, plastics will be suitable substrates for the microbial community. The macroplastic waste in the waters is a durable substrate and provides an attachment site for various kinds of micro and macro-organisms in the seas. Indigenous bacteria in aquatic habitats will be able to attach and form a biofilm layer within about one week after plastic materials, such as PET (polyethylene terephthalate), PVC (polyvinyl chloride), and PS (polystyrene), submerged in water. In addition, the microalgae from the Diatom, Cyanobacteria, and Coccolithophores groups are among the fastest and earliest microbial groups to attach and form colonies on plastic substrates covered by microbial biofilms (Casabianca et al., 2019; Eich et al., 2015).

Biofilm microbial growth can cause damage to the plastic surface and initiate the polymer degradation process (Rummel et al., 2017). The plastic degradation process is a complex process involving a consortium of microorganisms in the biofilm. Biofilm composition on the plastic surface are influenced by several factors, including the type of plastic polymer, nutrition, geographic location, and environmental exposure (Amaral-Zettler et al., 2015; Jiang et al., 2018; McCormick et al., 2014; Oberbeckmann et al., 2018). Schlundt et al. 2020 showed that geographical location has a greater impact on the formation of microbial biofilms. Microbial biofilms formation is faster in tropical than sub-tropical waters (Schlundt et al., 2020).

\section{BIODIVERSITY OF PLASTISPHERE IN TROPICAL ENVIRONMENT}

\section{Bacteria}

Bacteria are the initiators of microorganisms and the most dominant organism in the plastisphere. The search of a literature study using the Scopus machine showed that 69 articles focused on microorganisms' biodiversity in plastic surfaces for both macro and microplastics during the last ten years. It is known that the tropical region has the greatest level of biodiversity. However, the number of papers on microorganisms' biodiversity in plastic surfaces is still low. Among these articles, $43.5 \%$ concern the studies on the biodiversity of microorganisms that colonize on plastic in the temperate zone, followed by $42 \%$ percent in the subtropics and $14.5 \%$ in the tropical region. Although, the effect of latitude is still controversial in the diversity of microorganisms (Amend et al., 2013; Fuhrman et al., 2008; Ladau et al., 2013; Pommier et al., 2007; Raes et al., 2018). A study on the patterns of species richness along the latitudinal gradient from tropical waters of the US Virgin Islands $\left(12.0^{\circ} \mathrm{N}\right)$ to the temperate waters off Cap $\operatorname{Cod}\left(41.5^{\circ} \mathrm{N}\right)$ found that tropical areas have a greater bacterial richness than temperate areas (Amaral-Zettler et al., 2015). However, the number of studies about the microbial biodiversity of plastisphere in tropical regions is the least, compared to other regions. A study of microbial biodiversity on a plastic surface in the tropical environment based on the natural existing biofilm and in situ experiment including one-time collection or time series sample collection was found (Table 1). SEM microscopy analysis of the surface of a naturally existing microbial biofilm in the Victoria Bay area of Brazil revealed that the plastisphere is inhabited by a variety of microorganisms, including bacteria, bacterial spores, filamentous fungus, and even diatom remains (Baptista Neto et al., 2019). Bacteria are the initiators of microorganisms and the most dominant organism in the plastisphere. The plastic with larger sizes can become new habitats for these organisms including cyanobacteria, diatoms, bryozoans, polychaetes and barnacles (Abed et al., 2020; Muthukrishnan et al., 2019; Schlundt et al., 2020).

Proteobacteria, Bacteriodetes, and Firmicutes were the dominant phyla found on microplastic surfaces on sandy beaches along the coast of Singapore. However, there are very significant differences in the dominant genera. The environmental factor influences the differences of dominant genera in these microplastics. The virgin area was dominated by Brachymonas, Pseudomonas, and Sphingobium, whereas Arcobacter, Albimonas, and Bacteroides dominated the moderately populated area. In the areas with a high impact of anthropogenic activities, the dominant bacteria are Erythrobacter, Cohaesibacter, and Hyphomonas. Interestingly, the number of dominant bacteria in pristine and moderate areas was only about $5-6 \%$ for each genus. Still, the Erytrobacter genera appeared in very high numbers, reaching $21 \%$ of the inhabitants of the plastisphere. Erythrobacter is known as a hydrocarbon-degrading bacteria (Curren \& Leong, 2019). Generally, plastics are 
derived from petroleum products and have a long carbon chain structure. Therefore, the attachment of Erythrobacter on the plastic surface is closely related to the structure of the plastic.

Bacterial biofilm formation consists of several stages, including attachment, initiated when bacteria extrude extracellular polymeric substances (EPS); early-stage biofilm which is indicated by microorganisms that are already irreversibly attached; and mature biofilm (Renner \& Weibel, 2011). In contrast to the existing natural biofilms, microbial biodiversity at the same stage of biofilm formation can be identified and compared using in situ experiments. However, from several studies on biofilm formation using in situ experiment, it can be concluded that there are different community structures and formation rates between temperate and tropical zones. (Rajeev et al., 2019) stated that the dominance of primary colonizers at early-stage biofilms formation in the tropical zone is different from the temperate zone. These results are still in line with the indications of an early-stage biofilm that Proteobacteria dominate. The 72 hours-old biofilm from Kundakulam, India, has a Gammaproteobacteria as a dominant primary colonizer. In comparison, some studies in the temperate zone concluded that the Rhodobacteraceae family of Alphaproteobacteria dominates at the early phase of bacterial biofilm formation (Dang et al., 2008; Jones et al., 2007; Schlundt et al., 2020). Schlundt et al. 2020 also mentioned that the biofilm of plastic in the tropical ocean has a high diverse bacterial community. Early-stage biofilm formation is not only dominated by Rhodobacteraceae but also other genera from Alpha and Gammaproteobacteria. The complexity of microbial community in tropical zone is followed by the attachment of organic material and EPS production that occur faster compared to other zones. In situ experiments using nine different plastic types were conducted in the Zhangziang mangrove area for three months. All taxa of bacteria in the mangrove rhizosphere were also found on plastic surfaces. However, plastic biofilms have higher diversity with more taxa of bacteria. The capability of the plastic to adsorb organic and inorganic compounds facilitates the metabolism of microorganisms in the plastisphere and creates similar conditions with sediment only $2-3 \mathrm{~cm}$ apart. (Xie et al., 2021) showed that biofilms succession in plastic surfaces is influenced by the surrounding environment and the chemotaxis ability of bacteria. Bacterial growth on the surface of polymers such as acrylonitrile butadiene styrene (ABS), polycarbonate, and polyethylene terephthalate is more influenced by environmental factors than the type of plastic. The first month in the initial phase of

Table 1. Study in microorganism community of plastisphere in the tropical marine environment

\begin{tabular}{|c|c|c|c|c|c|}
\hline Geographical location & Habitat & Sampling methods & Plastic size & Plastic-type & References \\
\hline $\begin{array}{l}\text { Zhanjiang Mangrove } \\
\text { National Nature Reserve }\end{array}$ & $\begin{array}{l}\text { Mangrove } \\
\text { rhizosphere }\end{array}$ & $\begin{array}{l}\text { In situ experiment } \\
\text { (30 and } 90 \text { days) }\end{array}$ & $\begin{array}{l}\text { Microplastic } \\
(1-3 \mathrm{~mm})\end{array}$ & $\begin{array}{l}\text { LDPE, PS, } \\
\text { EPS, PP, PC, } \\
\text { PA6, PVC, } \\
\text { PET, ABS }\end{array}$ & (Xie et al., 2021) \\
\hline $\begin{array}{l}\text { Kudankulam, South } \\
\text { Coast of India }\end{array}$ & Coastal & $\begin{array}{l}\text { In situ experiment } \\
\text { ( } 3 \text { days) }\end{array}$ & Macroplastic & PVC & (Rajeev et al., 2019) \\
\hline Singapore & Beach & Natural collection & Microplastic & $\mathrm{n} / \mathrm{a}$ & $\begin{array}{l}\text { (Curren \& Leong, } \\
\text { 2019) }\end{array}$ \\
\hline Tropical atlantic & Deep sea & Natural collection & Macroplastic & PE, PA, PVC & $\begin{array}{l}\text { (Woodall Id et al., } \\
\text { 2018) }\end{array}$ \\
\hline $\begin{array}{l}\text { Marina Shangri La, } \\
\text { Muscat Oman }\end{array}$ & Enclosed bay & $\begin{array}{l}\text { In situ experiment } \\
\text { (20 and } 80 \text { days) }\end{array}$ & Macroplastic & $\begin{array}{l}\text { OXO-PE, PE, } \\
\text { PET }\end{array}$ & (Abed et al., 2020) \\
\hline $\begin{array}{l}\text { Coastal ocean surface } \\
\text { of the Tropical Atlantic } \\
\text { Ocean }\end{array}$ & Ocean & $\begin{array}{l}\text { In situ experiment } \\
\text { ( } 7 \text { and } 14 \text { days) }\end{array}$ & Microplastic & Polyethylene & (Schlundt et al., 2020) \\
\hline Sea of Oman & Coastal & $\begin{array}{l}\text { In situ experiment } \\
\text { (30 days) }\end{array}$ & Macroplastic & PET, PE & $\begin{array}{l}\text { (Muthukrishnan et al., } \\
\text { 2019) }\end{array}$ \\
\hline $\begin{array}{l}\text { Tropical waters of } \\
\text { the US Virgin Islands } \\
\left(12.0^{\circ} \mathrm{N}\right) \text { to the } \\
\text { temperate waters off } \\
\text { Cape Cod }\left(41.5^{\circ} \mathrm{N}\right)\end{array}$ & $\begin{array}{l}\text { Coastal and } \\
\text { open ocean }\end{array}$ & Natural collection & Microplastic & $\mathrm{n} / \mathrm{a}$ & $\begin{array}{l}\text { (Amaral-Zettler et al., } \\
\text { 2015) }\end{array}$ \\
\hline $\begin{array}{l}\text { Vitória Bay estuarine } \\
\text { system (SVB), SE Brazil }\end{array}$ & $\begin{array}{l}\text { Estuarine } \\
\text { sediment }\end{array}$ & Natural collection & Microplastic & $\mathrm{n} / \mathrm{a}$ & $\begin{array}{l}\text { (Baptista Neto et al., } \\
\text { 2019) }\end{array}$ \\
\hline Guanabara Bay, Brazil & $\begin{array}{l}\text { Mangrove, river, } \\
\text { beach }\end{array}$ & Natural collection & Macroplastic & PE, PP, PET & (Silva et al., 2019) \\
\hline
\end{tabular}


biofilm formation showed that the dominance of microorganisms in the same kind of plastic was different according to the immersion location. On the other hand, Abed et al. 2020 showed that bacterial communities were replaced by specialists (plastic-specific) after biofilm maturation ( $>80$ days) at Marina Shangri La, Muscat Oman. It was also indicated by the decrease in shared OTUs between several plastics.

Several studies have also shown that pathogenic bacteria can be associated with plastic debris. A predominance of Vibrionales was found in PS, PE, and PET polymers in Zhangjiang China (Xie et al., 2021). Meanwhile, Curren and Leong (2019) stated that a study on the coast of Singapore showed that the genus Vibrio in smaller percentage (less than $0.2 \%$ ) was found in microplastics at any kind of beachs (pristine, moderate, and heavily populated). Silva et al. (2019) reported that 59 strains of the genus Vibrio were found inhabiting the plastisphere belonging to V. mimicus, $V$. vulnificus, and $V$. cholerae. Interestingly, no species of $V$. Parahaemoliticus was found, which is a Vibrio species in marine habitats. Meanwhile, Xie et al. (2021) identified Vibrio parahaemolyticus and Escherichia-Shigella in plastic surfaces collected from the mangrove areas in China. Spirochetes pathogenic bacteria were also found in polystyrene and PA6 surface (Xie et al., 2021).

The growth of microorganisms in plastic polymers is able to initiate the degradation of plastic polymers, affecting the density, buoyancy, and sinking rate of plastics (Rummel et al., 2017). Tropical mangrove areas being polluted by plastic debris can be a habitat for plastic-degrading microorganisms. Incubation of plastic material in the mangrove area for three months contributed a pitting on the plastic surface, i.e., low-density polyethylene, polyamide 6 , and polyvinyl chloride. These results indicate a plastic degradation process carried out by microorganisms. Hydrocarbon degrading bacteria are known to be the dominant bacteria in the two types of plastic (Xie et al., 2021). The plastic type seems to affect the formation of bacterial biofilm shown by the dominance of Erythrobacter on the surface of polyamide 6 polymer (Xie et al., 2021), the occurrence of genera Alteromonas and Zoogloea that were only detected on the OXO-PE polymer (Abed et al., 2020), and highest relative abundance of Actinobacteria i.e. Aciditerrimonas, Streptomyces and Ilumatobacter on PET (Abed et al., 2020; Muthukrishnan et al., 2019). This polymer is composed of aminocaproic acid, which has a carbonyl functional group. Erytrobacter is known to be a bacterium that can utilize the carbonyl group for its metabolism (Xie et al., 2021). Therefore, the attachment of these genera on the plastic surface is closely related to the plastic structure. In addition, hydrocarbon-degrading bacteria were also detected dominantly in the areas with the highest microplastic pollution along the Singapore coast (Curren \& Leong, 2019). Generally, plastics are derived from petroleum products and have a long carbon chain structure. It increases the potential use of hydrocarbon-degrading bacteria to overcome the massive plastic pollution.

\section{Benthic microalgae and invertebrates}

Plastic debris provides a new surface for the growth of biofilm producers, such as bacteria and microalgae, which supported the growth of benthic invertebrates and later on formed a community consisting of both phototrophic and heterotrophic organisms (Eich et al., 2015). Diatoms were one of the first colonizer and also the most commonly abundant microalge on the plastic debris in the ocean (Amaral-Zettler et al., 2020; Carson et al., 2013; Eich et al., 2015; Muthukrishnan et al., 2019; Reisser et al., 2014). As photoautotrophs, the diatoms tend to colonize the marine plastic debris that is exposed to the sunlight (Amaral-Zettler et al., 2020). Among the diatoms group, pennate diatoms, particularly of the genera Mastogloia, Haslea, Frustulia, Diploneis, Ardissonea, Fragilaria, Protoraphis, and Thalassionema were commonly found and abundant on the plastic debris in the Northeast Pacific Ocean (Carson et al., 2013). Similarly, a study on the plastic debris in the coastal areas around Australia found other diatom genera, such as Nitzschia, Licmophora, Grammatophora, Amphora, Thalassionema, Microtabella, Achnanthes, Cocconeis, Navicula, Minidiscus, and Cymbella, with the Nitzchia spp. as the most common and abundant genus living on the Australian plastic debris (Reisser et al., 2014). Similar diatoms genera were also reported on the marine plastic debris sampled from the coastal area of Northwest Mediterranean Sea (Masó et al., 2016). Aside of diatoms, calcareous coccolithophores species, such as Calcidiscus leptoporus, Emiliania luxleyi, Coccolithus pelagicus, Calciosolenia sp., Gephyrocapsa oceanica, Umbellosphaera 
tenuis, and Umbilicosphaera hulburtiana, were also reported on the plastic debris from Southern Australian coast (Reisser et al., 2014). On the other hand, several benthic dinoflagellates genera, such as Coolia, Ostreopsis, Prorocentrum, and Alexandrium (Alexandrium taylori), were reported from plastic debris in the coast of Costa Brava, northeastern Spain (Masó et al., 2003) and Northwest Mediterranean Sea (Masó et al., 2016). Additionally, filamentous cyanobacteria are often present on the surface of marine plastic debris, although some studies, such as (Masó et al., 2003), (Reisser et al., 2014), (Masó et al., 2016), and (Schlundt et al., 2020), did not perform any taxonomic identification on this particular group. Even so, Zettler et al. (2013) reported the presence of Operational Taxonomic Unit (OTU) of two filamentous cyanobacteria genera from plastic debris, which were Phormidium and Rivularia in their research in North Atlantic Sub-tropical Gyre. Similarly, a study by (Bryant et al., 2016) on the marine plastic sampled from North Pacific Sub-tropical Gyre between Hawaiian Islands and California coast reported three filamentous cyanobacteria genera, which were Phormidium, Rivularia, and Leptolyngbya. A more detailed list of microalgae taxa reported colonizing the surface of marine plastic debris both in the coastal and oceanic systems are shown in Table 2.

On the other hand, benthic invertebrates, such as species from the taxa group of bryozoans, lepadomorph barnacles (Lepas), marine insect (Halobates), Asellote isopods, and marine worms were reported on drifted plastic debris sampled around the coastal waters of Australia (Reisser et al., 2014). A study on the rafting invertebrates on the marine plastic debris by Goldstein et al. (2014) in the Eastern and Western Pacific listed 11 phyla consisting of 95 identified taxa; the most abundant invertebrates were from the phylum Arthropoda, Mollusca, and Cnidaria. About 70 invertebrates taxa in Goldstein et al. (2014) study were known as common rafting invertebrates, such as barnacles (Lepas) and membraniporid bryozoans. On the other hand, about 40 invertebrates taxa on the plastic debris in the Eastern and Western Pacific were suspension feeders, about 20 taxa were omnivores, and the rest were grazer, predator, borer, and parasites (ecto- and endoparasite) (Goldstein et al., 2014). Several other predatory ciliates, such as choanoflagellates, Ephelota, and other suctorian ciliates, were reported as part of the plastisphere community in the oligotrophic oceanic ecosystem (Amaral-Zettler et al., 2020).

\section{POTENTIAL CANDIDATE FOR BIOREMEDIATION}

Substrate availability, surface characteristics, substrate form, and polymer molecular weight all contribute to the complex biodegradation process. Chemical, physical, or biological degradation can occur naturally. Microorganisms will act as effective bioremediation agents, contribute to the biological degradation process (Ammala et al., 2011; Harrison et al., 2018). There have been several studies on the use of microorganisms as bioremediation agents for plastic degradation. In bioremediation, microorganisms such as bacteria, actinomycetes, microalgae, and fungi, play a significant role. Plastic polymer, specifically petroleum-based plastic, show great promise for decomposition into monomers using bioremediation (Montazer et al., 2020). Microorganisms can biodegrade plastics and alter their physical qualities. In order to lessen plastic pollution in the environment, genetic engineering of microorganisms can enhance the enzymes produced by microorganisms to increase their ability to break down plastic waste into carbon dioxide.

\section{Bacteria}

Plastic waste is generally found in the areas where the population is quite dense, such as in coastal areas. Beaches have a high population density; thus, the abundance of plastic waste will also be high because it is influenced by the anthropogenic pressure. Proteobacteria and Bacteroides are two types of bacteria found in bacterial communities, and their distinctions vary by location. In previous studies, the characteristics of the bacterial community on the surface of marine microplastics revealed the same types of microorganisms (Amaral-Zettler et al., 2015; Oberbeckmann et al., 2016). Erythrobacter is more abundant in the areas with high levels of pollution. Plastic waste has been found to carry harmful bacteria such as Vibrio (Oberbeckmann et al., 2014) and Pseudomonas (Curren \& Leong, 2019). When plastic debris enters the water, it immediately develops a biofilm on the surface. Biofilms are made up of individual or consortia microbial species that are capable of degrading 
Table 2. Reported microalgae genera on drifted marine plastic debris from the taxa group of diatoms, dinoflagellates, coccolithophores and filamentous cyanobacteria

\begin{tabular}{|c|c|c|}
\hline Genus & Geographical region/location & References \\
\hline \multicolumn{3}{|c|}{ Diatoms } \\
\hline Achnanthes & North Western Mediterranean Sea; Coastal Australia & Maso et al., 2016; Reisser et al., 2014 \\
\hline Amphora & North Western Mediterranean Sea; Coastal Australia; Sea of Oman & Maso et al., 2016; Reisser et al., 2014; Muthukrishnan et al. 2019 \\
\hline Ardissonea & North East Pacific Ocean & Carson et al., 2013; \\
\hline Ceratoneis & North Western Mediterranean Sea & Maso et al., 2016; \\
\hline Chaetoceros & Coastal Australia; North Atlantic Sub-tropical Gyre & Reisser et al., 2014; Zettler et al., 2013 \\
\hline Cocconeis & North Western Mediterranean Sea; Coastal Australia & Maso et al., 2016; Reisser et al., 2014 \\
\hline Cyclotella & North Western Mediterranean Sea; Coastal Australia & Maso et al., 2016; Reisser et al., 2014 \\
\hline Cymbella & Coastal Australia & Reisser et al., 2014; \\
\hline Diploneis & North Western Mediterranean Sea; North East Pacific Ocean & Maso et al., 2016; Carson et al., 2013; \\
\hline Fragilaria & North East Pacific Ocean & Carson et al., 2013; \\
\hline Fragilariopsis & North Western Mediterranean Sea & Maso et al., 2016; \\
\hline Frustulia & North East Pacific Ocean & Carson et al., 2013; \\
\hline Grammatophora & Coastal Australia & Reisser et al., 2014; \\
\hline Haslea & North East Pacific Ocean; Coastal Australia & Carson et al., 2013; Reisser et al., 2014 \\
\hline Licmophora & North Western Mediterranean Sea; Coastal Australia; Sea of Oman & Maso et al., 2016; Reisser et al., 2014; Muthukrishnan et al. 2019 \\
\hline Mastogloia & $\begin{array}{l}\text { North Western Mediterranean Sea; North East Pacific Ocean; } \\
\text { Coastal Australia; Sea of Oman }\end{array}$ & $\begin{array}{l}\text { Maso et al., 2016; Carson et al., 2013; Reisser et al., 2014; } \\
\text { Muthukrishnan et al. } 2019\end{array}$ \\
\hline Microtabella & Coastal Australia & Reisser et al., 2014; \\
\hline Minidiscus & Coastal Australia & Reisser et al., 2014; \\
\hline Navicula & $\begin{array}{l}\text { North Western Mediterranean Sea; Coastal Australia; North } \\
\text { Atlantic Sub-tropical Gyre; Sea of Oman }\end{array}$ & $\begin{array}{l}\text { Maso et al., 2016; Reisser et al., 2014; Zettler et al., 2013; } \\
\text { Muthukrishnan et al. } 2019\end{array}$ \\
\hline Nitzschia & Coastal Australia; North Atlantic Sub-tropical Gyre; Sea of Oman & Reisser et al., 2014; Zettler et al., 2013; Muthukrishnan et al. 2019 \\
\hline Pleurosigma & Coastal Australia & Reisser et al., 2014; \\
\hline Protoraphis & North East Pacific Ocean & Carson et al., 2013; \\
\hline Sellaphora & Coastal Australia; North Atlantic Sub-tropical Gyre & Reisser et al., 2014; Zettler et al., 2013 \\
\hline Stauroneis & Coastal Australia; North Atlantic Sub-tropical Gyre & Reisser et al., 2014; Zettler et al., 2013 \\
\hline Striatella & North Western Mediterranean Sea & Maso et al., 2016; \\
\hline Thalassionema & North Western Mediterranean Sea; Coastal Australia & Maso et al., 2016; Reisser et al., 2014 \\
\hline Thalassiosira & North Western Mediterranean Sea; Coastal Australia & Maso et al., 2016; Reisser et al., 2014 \\
\hline Thalassiothrix & North Western Mediterranean Sea & Maso et al., 2016; \\
\hline \multicolumn{3}{|c|}{ Dinoflagellates } \\
\hline Alexandrium & Coastal Australia; Northeast Spain & Reisser et al., 2014; Maso et al., 2003 \\
\hline Ceratium & Coastal Australia; North Western Mediterranean Sea & Reisser et al., 2014; Maso et al., 2016 \\
\hline Coolia & Northeast Spain; North Western Mediterranean Sea & Maso et al., 2003; Maso et al., 2016 \\
\hline Dinophysis & North Western Mediterranean Sea & Maso et al., 2016 \\
\hline Heterocapsa & North Western Mediterranean Sea & Maso et al., 2016 \\
\hline Ostreopsis & Northeast Spain & Maso et al., 2003; \\
\hline Pentapharsodinium & North Western Mediterranean Sea & Maso et al., 2016 \\
\hline Prorocentrum & Northeast Spain; North Western Mediterranean Sea & Maso et al., 2003; Maso et al., 2016 \\
\hline \multicolumn{3}{|c|}{ Coccolithophores } \\
\hline Calcidiscus & North Western Mediterranean Sea; Coastal Australia & Maso et al., 2016; Reisser et al., 2014 \\
\hline Calciosolenia & Coastal Australia & Reisser et al., 2014 \\
\hline Calyptrosphaera & North Western Mediterranean Sea & Maso et al., 2016 \\
\hline Coccolithus & Coastal Australia & Reisser et al., 2014 \\
\hline Coronosphaera & North Western Mediterranean Sea & Maso et al., 2016 \\
\hline Emiliania & North Western Mediterranean Sea; Coastal Australia & Maso et al., 2016; Reisser et al., 2014 \\
\hline Gephyrocapsa & Coastal Australia & Reisser et al., 2014 \\
\hline Helicosphaera & North Western Mediterranean Sea & Maso et al., 2016 \\
\hline Rhabdosphaera & North Western Mediterranean Sea & Maso et al., 2016 \\
\hline Scyphosphaera & North Western Mediterranean Sea & Maso et al., 2016 \\
\hline Syracolithus & North Western Mediterranean Sea & Maso et al., 2016 \\
\hline Syracosphaera & North Western Mediterranean Sea & Maso et al., 2016 \\
\hline Umbellosphaera & Coastal Australia & Reisser et al., 2014 \\
\hline Umbilicosphaera & North Western Mediterranean Sea; Coastal Australia & Maso et al., 2016; Reisser et al., 2014 \\
\hline Zygosphaera & North Western Mediterranean Sea & Maso et al., 2016 \\
\hline \multicolumn{3}{|c|}{ Filamentous Cyanobacteria } \\
\hline Leptolyngbya & North Pacific Sub-tropical Gyre & Bryant et al., 2016 \\
\hline Phormidium & North Atlantic Sub-tropical Gyre; North Pacific Sub-tropical Gyre & Zettler et al., 2013; Bryant et al., 2016 \\
\hline Rivularia & North Atlantic Sub-tropical Gyre; North Pacific Sub-tropical Gyre & Zettler et al., 2013; Bryant et al., 2016 \\
\hline
\end{tabular}


polymers (Debroas et al., 2017). According to Curren \& Leong (2019), plastic waste samples contain 35 dominating species. Rhodobacterales, Oceanospirillales, and Burkholderiales are some of the most common orders of bacteria in the plastisphere. Primary colonizers and secondary consumers are thought to account for the majority of biofilm in inhabitants; nevertheless, species within this varied community could play a key role in the plastic degrading pathway. Many studies have been conducted in order to identify the greatest bacterial candidates for degrading plastics. However, the research on marine bacteria that can break down microplastics effectively is still limited, particularly in the tropics. In this review, the Publish or Perish program is used to conduct a review of the studies on the bacteria that can degrade plastics, particularly in the

Table 3. Study of biodegradable plastic from marine bacteria in tropical and subtropical areas

\begin{tabular}{|c|c|c|c|c|}
\hline Location & Bacteria & Type of plastic & Result & Cites \\
\hline \multicolumn{5}{|c|}{ Tropical } \\
\hline $\begin{array}{l}\text { Sea water of Bay of } \\
\text { Bengal near Puri, India }\end{array}$ & Alicaligens faecalis & $\begin{array}{l}\text { Polyethylene bags (BP: } \\
\text { black plastic; WP: white } \\
\text { plastic) }\end{array}$ & $\begin{array}{l}\text { It was found that LNDR-1 (Alcaligens faecalis) had } \\
\text { a better decay rate of } 15.25 \pm 1 \% \text { and } 21.72 \pm 2.1 \% \\
\text { for black and white plastic bags respectively in } 10 \\
\text { weeks without prior oxidation as compared to S. } \\
\text { marcescens. }\end{array}$ & (Nag et al., 2021) \\
\hline Tamil Nadu, India & $\begin{array}{l}\text { Bacillus spp. and } \\
\text { Pseudomonas spp }\end{array}$ & HDPE & $\begin{array}{l}\text { The identification of efficient HDPE degrading } \\
\text { isolates confirms that most of the bacterial isolates } \\
\text { belong to the genus Bacillus spp. and Pseudomonas } \\
\text { spp. }\end{array}$ & $\begin{array}{l}\text { (Sangeetha et al., } \\
\text { 2019) }\end{array}$ \\
\hline $\begin{array}{l}\text { Dumpsites of Gulf of } \\
\text { Mannar }\end{array}$ & $\begin{array}{l}\text { Arthrobacter sp. and } \\
\text { Pseudomonas sp. }\end{array}$ & HDPE & $\begin{array}{l}\text { After } 30 \text { days of incubation, Arthrobacter sp. lost } \\
\text { nearly } 12 \% \text { of its weight, while Pseudomonas sp. } \\
\text { lost } 15 \% \text { of its weight. }\end{array}$ & $\begin{array}{l}\text { (Balasubramanian } \\
\text { et al., 2010) }\end{array}$ \\
\hline $\begin{array}{l}\text { Magrove area in } \\
\text { Malayasia }\end{array}$ & $\begin{array}{l}\text { Rhodococcus sp. } \\
\text { and Bacilus sp. }\end{array}$ & Polypropelene & $\begin{array}{l}\text { The weight loss was } 6.4 \% \text { by Rhodococcus sp. } \\
\text { strain } 36 \text { and } 4.0 \% \text { by Bacillus sp. strain } 27 \text { after } 40 \\
\text { days of incubation }\end{array}$ & (Auta et al., 2018) \\
\hline $\begin{array}{l}\text { Mangrove area in } \\
\text { Peninsular Malaysia }\end{array}$ & $\begin{array}{l}\text { Consortia bacteria } \\
\text { from mangrove } \\
\text { sediment }\end{array}$ & $\begin{array}{l}\text { Polyethylene, polyethylene } \\
\text { terephthalate, } \\
\text { polypropylene, polystyrene }\end{array}$ & $\begin{array}{l}38 \text { species was isolated from mangrove sediment } \\
\text { reduced polyethylene }(27.9 \%) \text {; polyethylene } \\
\text { terephtalate }(24 \%) \text {, polypropylene }(19.5 \%) \\
\text { polystyrene }(15 \%)\end{array}$ & (Syamimi, 2018) \\
\hline \multicolumn{5}{|c|}{ Subtropics } \\
\hline $\begin{array}{l}\text { The Soyang river and } \\
\text { the shores of Busan and } \\
\text { Jeju Island }\end{array}$ & Bacillus sp. JY14 & Polyhydroxybutyrate & $\begin{array}{l}\text { Approximately } 98 \% \text { PHB degradation within two } \\
\text { weeks }\end{array}$ & (Cho et al., 2021) \\
\hline $\begin{array}{l}\text { Intertidal of Zhanziang } \\
\text { Bay, China }\end{array}$ & $\begin{array}{l}\text { Mycolicibacterium } \\
\text { phocaicum }\end{array}$ & $\begin{array}{l}\text { Di-(2-ethylhexyl) phthalate } \\
\text { (DEHP) }\end{array}$ & $\begin{array}{l}\text { Mycolicibacterium phocaicum could rapidly degrade } \\
\text { DEHP and achieve complete degradation of DEHP } \\
(50 \mathrm{mg} / \mathrm{L}) \text { in } 48 \mathrm{H} \text {, when Tween } 80 \text { was added as } \\
\text { solubilizing agent }\end{array}$ & (Ren et al., 2021) \\
\hline Mediterranean Sea & $\begin{array}{l}\text { Alcanivorax } \\
\text { borkumensis }\end{array}$ & $\begin{array}{l}\text { Low Density PolyEthylene } \\
\text { (LDPE), PolyEthylene } \\
\text { Terephthalate (PET) and } \\
\text { PolyStyrene (PS) }\end{array}$ & $\begin{array}{l}\text { Alcanovorax borkumensis had ability to form thick } \\
\text { biofilms specifically on LDPE and to degrade this } \\
\text { petroleum-based plastic. After } 96 \mathrm{~h} \text { and } 144 \mathrm{~h} \text { a } \\
\text { significantly higher percentage of biofilm associated } \\
\text { bacteria was abserved on LDPE, } 68.5 \% \text { and } 68.1 \% \\
\text { respectively. }\end{array}$ & $\begin{array}{l}\text { (Delacuvellerie et } \\
\text { al., 2019) }\end{array}$ \\
\hline $\begin{array}{l}\text { Dameisha coastline, } \\
\text { China }\end{array}$ & Rhodococcus ruber & $\begin{array}{l}\text { Di-(2-ethylehxyl) phthalate } \\
\text { (DEHP) }\end{array}$ & $\begin{array}{l}\text { Strain Rhodococcus ruber completely degraded } \\
100 \mathrm{mg} / \mathrm{L} \text { DEHP within three days }\left(\mathrm{pH} 7.0,30^{\circ} \mathrm{C}\right) \text {; } \\
\text { Furthermore, Rhodococcus ruber metabolized initial } \\
\text { concentrations of DEHP ranging from } 0.5 \text { to } 1000 \\
\mathrm{mg} / \mathrm{L} \text {. Especially, YC-YT1 degraded up to } 60 \% \text { of } \\
\text { the } 0.5 \mathrm{mg} / \mathrm{L} \text { initial DEHP concentration }\end{array}$ & (Yang et al., 2018) \\
\hline $\begin{array}{l}\text { Microcosm in lab } \\
\text { experiment }\end{array}$ & $\begin{array}{l}\text { Marine concortia } \\
\text { bacteria }\end{array}$ & $\begin{array}{l}\text { Low-density polyethylene } \\
\text { (LLDPE) }\end{array}$ & $\begin{array}{l}\text { The acclimated consortia (indigenous and } \\
\text { bioaugmented) reduced more efficiently the weight } \\
\text { of PE films in comparion to non-aclimated bacteria }\end{array}$ & $\begin{array}{l}\text { (Syranidou et al., } \\
\text { 2017) }\end{array}$ \\
\hline $\begin{array}{l}\text { Coastal seawater, } \\
\text { Suruga Bay, Japan }\end{array}$ & Shewanella spp. & $\begin{array}{l}\text { A poly[(R)-3- } \\
\text { hydroxybutyrate] }[\mathrm{P}(3 \mathrm{HB})]\end{array}$ & $\begin{array}{l}\text { The isolate was able to grow at temperature } 30 \text { - } \\
37^{\circ} \mathrm{C} \text {; however, the optimum isolate for degradation } \\
\text { of } \mathrm{P}(3 \mathrm{HB}) \text { was } 15^{\circ} \mathrm{C}\end{array}$ & (Sung et al., 2016) \\
\hline $\begin{array}{l}\text { Sediment samples of the } \\
\text { coast India }\end{array}$ & $\begin{array}{l}\text { Vibrio } \\
\text { parahemolyticus and } \\
\text { Vibrio alginolyticus }\end{array}$ & $\begin{array}{l}\text { Polyvinyl alcohol-low linear } \\
\text { density polyethylene (PVA- } \\
\text { LLDPE) }\end{array}$ & $\begin{array}{l}\text { Results indicated that relatively } 20 \% \text { decrease in } \\
\text { tensile strength of the film could be achieved with } 25 \\
\text { and } 30 \% \text { blend of PVA in the PVALLDPE plastic film } \\
\text { compared to other ratios }\end{array}$ & $\begin{array}{l}\text { (Raghul et al., } \\
\text { 2014) }\end{array}$ \\
\hline $\begin{array}{l}\text { Coastal seawater, } \\
\text { Okinoshima Park, Chiba, }\end{array}$ & $\begin{array}{l}\text { Pseudomonas } \\
\text { pachastrellae }\end{array}$ & $\begin{array}{l}\text { Polyester poly }(\varepsilon- \\
\text { caprolactone) (PCL) }\end{array}$ & $\begin{array}{l}\text { Pseudomonas pachastrellae JCM12285T; } \\
\text { Strain TKCM } 64 \text { degraded PCL film at a rate of } \\
1.39 \pm 0.09 \mathrm{mg} \mathrm{cm}^{-2} \cdot \text { day }^{-1} \text {. }\end{array}$ & $\begin{array}{l}\text { (Suzuki et al., } \\
\text { 2018) }\end{array}$ \\
\hline
\end{tabular}


tropics; from the data obtained, only a few studies have been conducted, as shown in Table 3. Several research results were discovered on the marine bacteria originating from the tropics in degrading microplastics, including Alicagens faecalis (Nag et al., 2021), Bacillus spp, Pseudomonas spp (Auta et al., 2018; Balasubramanian et al., 2010; Sangeetha et al., 2019), Arthrobacter sp. (Syamimi, 2018).

The community of plastic waste-degrading bacteria in the tropics has some similarities to those occurring in the subtropics. The bacteria from the genera Bacillus, Pseudomonas, and Rhodococcus are found in tropical and subtropical regions (Auta et al., 2018; Balasubramanian et al., 2010; Cho et al., 2021; Sangeetha et al., 2019; Suzuki et al., 2018; Yang et al., 2018). This can be the basis for the candidate bacteria that can degrade plastic waste. After 30 days of incubation, the bacteria from the genus Pseudomonas sp. can reduce the weight of HDPE by $15 \%$, according to Balasubramanian, et al. (2010). Meanwhile, bacteria Bacillus $s p$. isolated from tropical mangrove sediments can reduce the weight of Polypropelene granules by $4 \%$ (Auta et al., 2018). Bacillus sp. from the subtropics might breakdown Polyhydroxybutyrate (PHB) about $98 \%$ after two weeks, according to Cho, et al. (2021). This indicates that the bacteria belonging to the Pseudomonas $s p$. genus are present and Bacillus sp. are the best microorganisms for degrading microplastics, particularly in the tropics.

\section{Actinobacteria}

Among plastic polymer biodegraders, the most active taxa are fungi and actinobacteria (Tosin et al., 2012). Actinobacteria, often known as actinomycetes, are Gram-positive bacteria that have a high GC content. These bacteria can be found in a variety of ecological habitats, including soils, freshwater, and marine environments (Valan et al., 2012). Actinobacteria, one of many microorganisms, has been found attached to the marine environment plastic waste surface but seldom reported from tropical areas. On the basis of the literature study conducted, from 61 articles, sorted by 12 articles, only one article reported the presence of plastics-degrader actinobacteria in tropical environments. In contrast, most were reported from temperate regions.

Most actinobacteria are known as bioactive compounds producers, such as anticancer, antimicrobial, antifungal, and others, but recently those microorganisms have also been found to degrade complex polymers (Goodfellow, 1983; Sharma et al., 2014). Besides being known as a producer of many secondary metabolites, the marine actinobacteria are also reported for the degradation of oil spills, chlorobenzenes, aliphatic and polycyclic aromatic hydrocarbons (PAHs), polychlorinated biphenyls (PCBs), phenols, n-alkanes, heavy metal compounds, and plastic materials (Rathore et al., 2021). The actinobacteria are also reported to biodegrade various pollutants, such as pesticides, plastics, rubber, heavy metal, and other organic matters (Diez, 2010; Tseng et al., 2007). Actinobacteria are known to decompose a large number of biomolecules (lignin, cellulose, and hemicellulose) and to metabolize recalcitrant polymers such as long-chain n-alkanes (Lo Piccolo et al., 2011), xenobiotics (Borozan, 2013), pesticides (Alvarez et al., 2017), and rubber (Shivlata \& Satyanarayana, 2015).

The predominant genera of Actinobacteria in the degradation and bioremediation were reported by Rathore et al. (2021). They are Rhodococcus, Nocardiopsis, Streptomycetes, Gordonia, Dietzia, Actinopolyspora, Amycolicicoccus, Micrococcus, Arthrobacter, Salinispora, Micromonospora, Actinomadura, Streptosporangium, Streptomonospora, Prauserella, Pseudonocardia, Aeromicrobium, Marinactinospora, and Microbacterium. The Rhodococcus sp. seem the most reported actinobacteria-degrading microplastics. The actinobacterium Rhodococcus ruber, for example, is reported as a plastic degrader (Andrady, 2011) and produces biofilm, which helps to improve degradation (Auta et al., 2018). Other Rhodococcus such as polyethylene (PE)-degrader actinobacteria by Rhodococcus ruber strain C208 (Sivan et al., 2006), Rhodococcus rhodochrous ATCC 29672 (Bonhomme et al., 2003), polystyrene (PS) - degrader Rhodococcus ruber (Mor \& Sivan, 2008), and polypropylene (PP) - degrader Rhodococcus sp. strain 36 (Auta et al., 2018). The other actinobacteria have also been reported as plastics degraders, such as PE-degrader Micrococcus sp. (Kathiresan, 2003) and consortia of bacteria including actinobacteria (Nowak et al., 2011). Microbacterium paraoxydans was declared as polyethylene (PE)-degrader with nitric acid pretreatment (Rajandas et al., 2012). Hydrocarbondegrading bacteria, such as Alcanivorax, Marinobacter, and Arenibacter, have been found to be potential agents in plastic degradation, with Alcanivorax borkumensis chosen as a significant player in LDPE degradation (Delacuvellerie et al., 2019). 
The use of actinobacteria in plastics waste bioremediation has raised the hopes that the plastic problem will be solved in the future (Oliveira et al., 2020). The improvement was such that the Rhodococcus ruber of marine origin is reported to degrade plastic waste significantly. This organism can degrade $8 \%$ of dry weight of plastic waste within 30 days under in vitro conditions (Andrady, 2011). The use of Rhodococcus ruber strain C208, the initial signs of degradation appeared after only 16 days. R. ruber degraded 7.5 percent of the initial weight of the microplastic in only two months and could use PE as the sole carbon source (Sivan et al., 2006). Amycolatopsis orientalis expressed an extracellular PLAdegrading enzyme with high degrading activity, which resulted in the total degradation of the PLA powder within 8 hours. Additionally, the Kibdelosporangium aridum strain showed a high capacity for biodegradation, degrading almost 97 percent of the initial polymer. This strain formed several small pits across the PLA surface (Jarerat et al., 2003).

Some of the actinobacteria mentioned above are marine-derived actinomycetes. These revealed high polymer degradation, as well as polymer structural and chemical changes. Therefore, the marine actinomycete counterparts appear to be quite effective in using polymers as a sole carbon source, especially for PLA degradation (Oliveira et al., 2020). Most of the papers reported actinobacteria from the temperate zone, but only some studies informed plastics-degrader actinobacteria from a tropical area. Auta et al. (2018) investigated the growth response and mechanism of degradation of polypropylene (PP) by Bacillus sp. and Rhodococcus $\mathrm{sp}$. isolated from mangrove sediments in Peninsular Malaysia. These bacteria and actinobacteria strains were able to thrive on PP microplastic, as indicated by the polymer mass reduction. After 40 days of incubation, Rhodococcus sp. lost 6.4 percent of its weight while Bacillus sp. lost 4.0 percent of its weight. Harshvardhan \& Jha, (2013) reported sixty marine bacteria isolated from pelagic waters of the Arabian Sea coast, India, were screened for their ability to degrade low-density polyethylene; among them, Kocuria palustris M16, Bacillus pumilus $\mathrm{M} 27$ and Bacillus subtilis $\mathrm{H} 1584$ were positive and able to grow in a medium containing polythene as the sole carbon source.

\section{Benthic microalgae}

Marine microalgal taxa, particularly diatoms and cyanobacteria, are one of the first organisms that colonize a new substrate such as plastic debris. Those microalgae help the formation of biofilm by secreting polysaccharide substances that form Transparent Exopolymer Particles (TEPs) under turbulent conditions which help stabilize the biofilm and allow the diatoms or cyanobacteria cells to stick to the surface of the plastic debris (Casabianca et al., 2020; Ryabushko et al., 2021). However, whether the microalgae contribute directly towards the degradation of the plastic debris itself or not is still debatable. The microalgae were thought to contribute indirectly by promoting the growth of plastic degrading bacteria. The biofilm that formed with the help of microalgae and their metabolic waste could provide an additional substrate and nutrients for the bacteria that are capable of degrading some components of plastic, particularly the hydrocarbon compounds (Amaral-Zettler et al., 2020; Zettler et al., 2013). Meanwhile, the existence of bacteria on the biofilm could help provide essential nutrients and growth factors, such as vitamin B12, to the associated phototrophic microalgae (Amaral-Zettler et al., 2021). On the other hand, the biofilm that produced by microalgae and bacteria could prevent the plastic breakdown via reduced exposure to ultraviolet (UV) radiation (Masó et al., 2016; Schlundt et al., 2020). The additional weight of microalgae and other biofouling organisms also decreases the buoyancy and causes the plastic debris to sink faster to the aphotic zone and to the bottom of the ocean, which also reduces the degradation rate of the plastic itself (Eich et al., 2015; Smith et al., 2021).

\section{CONCLUSIONS}

The number of studies on microbial biodiversity of plastisphere in the tropical marine region is the least compared to the other regions. However, several studies have shown higher diversity and faster biofilm formation in tropical areas. The potential of microorganisms on plastic surfaces has not been studied further, although several studies have shown indications of the potential microorganisms as plastic degrading agents. The discovery of plastic degrading microorganisms 
in the tropical areas is also still very rare. Future research needs to focus on using the omics approach to understand gene or enzyme secretion by microorganisms in a biofilm of plastic to find their function. In addition, the isolation of microorganisms and analysis of their potential as plastic degrading from tropical marine environments is an essential part of further research.

\section{Acknowledgements}

The study was fully funded by LIPI's COREMAP-CTI 2021-2022 (17/A/DK/2021).

\section{REFERENCES}

1. Abed R.M.M., Muthukrishnan T., Al Khaburi M., Al-Senafi F., Munam A., Mahmoud H. 2020. Degradability and biofouling of oxo-biodegradable polyethylene in the planktonic and benthic zones of the Arabian Gulf. Marine Pollution Bulletin, 150, 110639. https://doi.org/10.1016/J. MARPOLBUL.2019.110639

2. Albertsson A.C., Andersson S.O., Karlsson S. 1987. The mechanism of biodegradation of polyethylene. Polymer Degradation and Stability, 18, 73-87. https://doi.org/10.1016/0141-3910(87)90084-X

3. Alvarez A., Saez J.M., Davila Costa J.S., Colin V.L., Fuentes M.S., Cuozzo S.A., Benimeli C. S., Polti M.A., Amoroso M.J. 2017. Actinobacteria: Current research and perspectives for bioremediation of pesticides and heavy metals. Chemosphere, 166, 41-62. https://doi.org/10.1016/j.chemosphere.2016.09.070

4. Amaral-Zettler L.A., Ballerini T., Zettler E.R., Asbun A.A., Adame A., Casotti R., Dumontet B., Donnarumma V., Engelmann J.C., Frère L., Mansui J., Philippon M., Pietrelli L., Sighicelli M. 2021. Diversity and predicted inter- and intra-domain interactions in the Mediterranean Plastisphere. Environmental Pollution, 286, 117439. https://doi.org/ https://doi.org/10.1016/j.envpol.2021.117439

5. Amaral-Zettler L.A., Zettler E.R., Mincer T.J. 2020. Ecology of the plastisphere. In Nature Reviews Microbiology, Nature Research, 18(3), 139-151. https://doi.org/10.1038/s41579-019-0308-0

6. Amaral-Zettler L.A., Zettler E.R., Slikas B., Boyd G.D., Melvin D.W., Morrall C.E., Proskurowski G., Mincer T.J. 2015. The biogeography of the Plastisphere: Implications for policy. Frontiers in Ecology and the Environment, 13(10), 541-546. https://doi. org/10.1890/150017

7. Amend A.S., Oliver T.A., Amaral-Zettler L.A., Boetius A., Fuhrman J.A., Horner-Devine M. C., Huse S.M., Welch D.B.M., Martiny A.C., Ramette
A., Zinger L., Sogin M.L., Martiny J.B.H. 2013. Macroecological patterns of marine bacteria on a global scale. Journal of Biogeography, 40, 800-811. https://doi.org/10.1111/jbi.12034

8. Ammala A., Bateman S., Dean K., Petinakis E., Sangwan P., Wong S., Yuan Q., Yu L., Patrick C., Leong K.H. 2011. An overview of degradable and biodegradable polyolefins. Progress in Polymer Science (Oxford), 36, 1015-1049. https://doi. org/10.1016/j.progpolymsci.2010.12.002

9. Andrady A.L. 2011. Microplastics in the marine environment. Marine Pollution Bulletin, 62(8), 1596-1605. https://doi.org/10.1016/J. MARPOLBUL.2011.05.030

10. Auta H.S., Emenike C.U., Jayanthi B., Fauziah S.H. 2018. Growth kinetics and biodeterioration of polypropylene microplastics by Bacillus sp. and Rhodococcus sp. isolated from mangrove sediment. Marine Pollution Bulletin, 127, 15-21. https://doi. org/10.1016/j.marpolbul.2017.11.036

11. Balasubramanian V., Natarajan K., Hemambika B., Ramesh N., Sumathi C.S., Kottaimuthu R., Rajesh Kannan V. 2010. High-density polyethylene (HDPE)-degrading potential bacteria from marine ecosystem of Gulf of Mannar, India. Letters in Applied Microbiology, 51(2), 205-211. https://doi. org/10.1111/j.1472-765X.2010.02883.x

12. Baptista Neto J.A., Gaylarde C., Beech I., Bastos A.C., da Silva Quaresma V., de Carvalho D.G. 2019. Microplastics and attached microorganisms in sediments of the Vitória bay estuarine system in SE Brazil. Ocean \& Coastal Management, 169, 247-253. https://doi.org/10.1016/J. OCECOAMAN.2018.12.030

13. Barnes D.K.A., Galgani F., Thompson R.C., Barlaz M. 2009. Accumulation and fragmentation of plastic debris in global environments. Philosophical Transactions of the Royal Society B: Biological Sciences, 364(1526), 1985-1998. https://doi.org/10.1098/ rstb.2008.0205

14. Bonhomme S., Cuer A., Delort A.M., Lemaire J., Sancelme M., Scott G. 2003. Environmental biodegradation of polyethylene. Polymer Degradation and Stability, 81(3), 441-452. https://doi.org/10.1016/ S0141-3910(03)00129-0

15. Borozan D. 2013. Exploring the relationship between energy consumption and GDP: Evidence from Croatia. Energy Policy, 59, 373-381. https:// doi.org/10.1016/j.enpol.2013.03.061

16. Bryant J.A., Clemente T.M., Viviani D.A., Fong A.A., Thomas K.A., Kemp P., Karl D.M., White A.E., DeLong E.F., Jansson J.K. 2016. Diversity and Activity of Communities Inhabiting Plastic Debris in the North Pacific Gyre. MSystems, 1(3), e0002416. https://doi.org/doi:10.1128/mSystems.00024-16

17. Carson H.S., Nerheim M.S., Carroll K.A., Eriksen 
M. 2013. The plastic-associated microorganisms of the North Pacific Gyre. Marine Pollution Bulletin, 75(1), 126-132. https://doi.org/https://doi. org/10.1016/j.marpolbul.2013.07.054

18. Casabianca S., Capellacci S., Giacobbe M.G., Dell'Aversano C., Tartaglione L., Varriale F., Narizzano R., Risso F., Moretto P., Dagnino A., Bertolotto R., Barbone E., Ungaro N., Penna A. 2019. Plastic-associated harmful microalgal assemblages in marine environment. Environmental Pollution, 244, 617-626. https://doi.org/10.1016/j. envpol.2018.09.110

19. Casabianca S., Capellacci S., Penna A., Cangiotti M., Fattori A., Corsi I., Ottaviani M.F., Carloni R. 2020. Physical interactions between marine phytoplankton and PET plastics in seawater. Chemosphere, 238, 124560. https://doi.org/https://doi. org/10.1016/j.chemosphere.2019.124560

20. Cho J.Y., Lee Park S., Lee H.J., Kim S.H., Suh M.J., Ham S., Bhatia S.K., Gurav R., Park S. H., Park K., Yoo D., Yang Y.H. 2021. Polyhydroxyalkanoates (PHAs) degradation by the newly isolated marine Bacillus sp. JY14. Chemosphere, 283, 131172. https:// doi.org/10.1016/J.CHEMOSPHERE.2021.131172

21. Curren, E., Leong S.C.Y. 2019. Profiles of bacterial assemblages from microplastics of tropical coastal environments. Science of the Total Environment, 655, 313-320. https://doi.org/10.1016/j. scitotenv.2018.11.250

22. Dang H., Li T., Chen M., Huang G. 2008. Crossocean distribution of Rhodobacterales bacteria as primary surface colonizers in temperate coastal marine waters. Applied and Environmental Microbiology, 74(1), 52-60. https://doi.org/10.1128/ AEM.01400-07

23. Debroas D., Anne M., Alexandra T.H. 2017. Plastics in the North Atlantic garbage patch: A boat-microbe for hitchhikers and plastic degraders. Science of the Total Environment, 599-600, 1222-1232. https:// doi.org/10.1016/j.scitotenv.2017.05.059

24. Delacuvellerie A., Cyriaque V., Gobert S., Benali S., Wattiez R. 2019. The plastisphere in marine ecosystem hosts potential specific microbial degraders including Alcanivorax borkumensis as a key player for the low-density polyethylene degradation. Journal of Hazardous Materials, 380, 120899. https:// doi.org/10.1016/j.jhazmat.2019.120899

25. Diez M.C. 2010. Biological aspects involved in the degradation of organic pollutants. Journal of Soil Science and Plant Nutrition, 10(3), 244-267. https:// doi.org/10.4067/S0718-95162010000100004

26. Eich A., Mildenberger T., Laforsch C., Weber M. 2015. Biofilm and diatom succession on polyethylene (PE) and biodegradable plastic bags in two marine habitats: Early signs of degradation in the pelagic and benthic zone? PLoS ONE, 10. https:// doi.org/10.1371/journal.pone.0137201

27. Flemming H.C., Wingender J. 2010. The biofilm matrix. Nature Reviews Microbiology, 8(9), 623633. https://doi.org/10.1038/nrmicro2415

28. Fuhrman J.A., Steele J.A., Hewson I., Schwalbach M.S., Brown M.V, Green J.L., Brown J.H. 2008. A latitudinal diversity gradient in planktonic marine bacteria. PNAS, 105(22), 7774-7778. https://doi. org/10.1073/pnas.0803070105

29. Galgani F., Hanke G., Maes T. 2015. Global Distribution, Composition and Abundance of Marine Litter. Marine Anthropogenic Litter, 29-56. https:// doi.org/10.1007/978-3-319-16510-3

30. Galgani L., Engel A., Rossi C., Donati A., Loiselle S.A. 2018. Polystyrene microplastics increase microbial release of marine Chromophoric Dissolved Organic Matter in microcosm experiments. Scientific Reports, 8(1), 1-11. https://doi.org/10.1038/ s41598-018-32805-4

31. Geyer R., Jambeck J.R., Law K.L. 2017. Production, use, and fate of all plastics ever made. Science Advances, 3(7), e1700782-e1700782. https://doi. org/10.1126/sciadv.1700782

32. Goldstein M.C., Carson H.S., Eriksen M. 2014. Relationship of diversity and habitat area in North Pacific plastic-associated rafting communities. Marine Biology, 161(6), 1441-1453. https://doi. org/10.1007/s00227-014-2432-8

33. Goodfellow M. 1983. The actinomyces of the soil. Ann. Rev. Microbial, 37, 189-216. https://doi. org/10.1097/00010694-191602000-00001

34. Harrison J.P., Boardman C., O'Callaghan K., Delort A.M., Song J. 2018. Biodegradability standards for carrier bags and plastic films in aquatic environments: a critical review. Royal Society Open Science, 5(5), 171792. https://doi. org/10.1098/RSOS.171792

35. Harshvardhan K., Jha B. 2013. Biodegradation of low-density polyethylene by marine bacteria from pelagic waters, Arabian Sea, India. Marine Pollution Bulletin, 77(1-2), 100-106. https://doi. org/10.1016/j.marpolbul.2013.10.025

36. Hwang J., Choi D., Han S., Jung S.Y., Choi J., Hong J. 2020. Potential toxicity of polystyrene microplastic particles. Scientific Reports, 10(1), 1-12. https:// doi.org/10.1038/s41598-020-64464-9

37. Iñiguez M.E., Conesa J.A., Fullana A. 2017. Pollutant content in marine debris and characterization by thermal decomposition. Marine Pollution Bulletin, 117(1-2), 359-365. https://doi.org/10.1016/j. marpolbul.2017.02.022

38. Jambeck J.R., Geyer R., Wilcox C., Siegler T.R., Perryman M., Andrady A., Narayan R., Law K.L. 2015. Plastic waste inputs from land into the ocean. Science, 347(6223), 768-771. https://doi. 
org/10.1126/science. 1260352

39. Jarerat A., Tokiwa Y., Tanaka H. 2003. Poly(L-lactide) degradation by Kibdelosporangium aridum. Biotechnology Letters, 25(23), 2035-2038. https:// doi.org/10.1023/B:BILE.0000004398.38799.29

40. Jiang P., Zhao S., Zhu L., Li D. 2018. Microplastic-associated bacterial assemblages in the intertidal zone of the Yangtze Estuary. Science of the Total Environment. https://doi.org/10.1016/j. scitotenv.2017.12.105

41. Jones P.R., Cottrell M.T., Kirchman D.L., Dexter S.C. 2007. Bacterial community structure of biofilms on artificial surfaces in an estuary. Microbial Ecology, 53, 153-162. https://doi.org/10.1007/ s00248-006-9154-5

42. Kathiresan K. 2003. Polythene and plastic-degrading microbes in an Indian mangrove soil. Revista de Biologia Tropical, 51(3-4), 629-633. http:/www. ncbi.nlm.nih.gov/pubmed/15162769

43. Ladau J., Sharpton T.J., Finucane M.M., Jospin G., Kembel S.W., O’Dwyer J., Koeppel A.F., Green J.L., Pollard K.S. 2013. Global marine bacterial diversity peaks at high latitudes in winter. ISME Journal. https://doi.org/10.1038/ismej.2013.37

44. Lo Piccolo L., de Pasquale C., Fodale R., Puglia A.M., Quatrini P. 2011. Involvement of an alkane hydroxylase system of Gordonia sp. strain SoCg in degradation of solid n-alkanes. In Applied and Environmental Microbiology, 77(4), 1204-1213. https:// doi.org/10.1128/AEM.02180-10

45. Lobelle D., Cunliffe M. 2011. Early microbial biofilm formation on marine plastic debris. Marine Pollution Bulletin, 62(1), 197-200. https://doi. org/10.1016/J.MARPOLBUL.2010.10.013

46. Maes T., Jessop R., Wellner N., Haupt K., Mayes A.G. 2017. A rapid-screening approach to detect and quantify microplastics based on fluorescent tagging with Nile Red. Scientific Reports, 7, 1-10. https:// doi.org/10.1038/srep44501

47. Masó M., Fortuño J.M., De Juan S., Demestre M. 2016. Microfouling communities from pelagic and benthic marine plastic debris sampled across Mediterranean coastal waters. Scientia Marina, 80, 117-127. https://doi.org/10.3989/scimar.04281.10a

48. Masó M., Garcés E., Pagès F., Camp J. 2003. Drifting plastic debris as a potential vector for dispersing Harmful Algal Bloom (HAB) species. Scientia Marina, 67(1), 107-111. https://doi.org/10.3989/ scimar.2003.67n 1107

49. McCormick A., Hoellein T.J., Mason S.A., Schluep J., Kelly J.J. 2014. Microplastic is an abundant and distinct microbial habitat in an urban river. Environmental Science and Technology. https://doi. org/10.1021/es503610r

50. Montazer Z., Habibi Najafi M.B., Levin D.B. 2020.
Challenges with Verifying Microbial Degradation of Polyethylene. Polymers, 12(1), 123. https://doi. org/10.3390/polym12010123

51. Mor R., Sivan A. 2008. Biofilm formation and partial biodegradation of polystyrene by the actinomycete Rhodococcus ruber: Biodegradation of polystyrene. Biodegradation, 19(6), 851-858. https://doi. org/10.1007/s10532-008-9188-0

52. Muthukrishnan T., Al Khaburi M., Raeid, Abed M.M. 2019. Fouling Microbial Communities on Plastics Compared with Wood and Steel: Are They Substrate-or Location-Specific? Microbial Ecology, 78, 361-374. https://doi.org/10.1007/ s00248-018-1303-0

53. Nag M., Lahiri D., Dutta B., Jadav G., Ray R.R. 2021. Biodegradation of used polyethylene bags by a new marine strain of Alcaligenes faecalis LNDR-1. Environmental Science and Pollution Research, 28, 41365-41379. https://doi.org/10.1007/ s11356-021-13704-0

54. Nowak B., Pajak J., Drozd-Bratkowicz M., Rymarz G. 2011. Microorganisms participating in the biodegradation of modified polyethylene films in different soils under laboratory conditions. International Biodeterioration and Biodegradation, 65(6), 757767. https://doi.org/10.1016/j.ibiod.2011.04.007

55. Oberbeckmann S., Kreikemeyer B., Labrenz M. 2018. Environmental Factors Support the Formation of Specific Bacterial Assemblages on Microplastics. Frontiers in Microbiology, 8, 2709. https:// doi.org/10.3389/fmicb.2017.02709

56. Oberbeckmann S., Loeder M.G.J., Gerdts G., Osborn A.M. 2014. Spatial and seasonal variation in diversity and structure of microbial biofilms on marine plastics in Northern European waters. FEMS Microbiology Ecology, 90(2), 478-492. https://doi. org/10.1111/1574-6941.12409

57. Oberbeckmann S., Osborn A.M., Duhaime M.B. 2016. Microbes on a Bottle: Substrate, Season and Geography Influence Community Composition of Microbes Colonizing Marine Plastic Debris. PLOS ONE, 11(8), e0159289. https://doi.org/10.1371/ journal.pone.0159289

58. Oliveira J., Belchior A., Silva V.D., Rotter A., Petrovski Ž., Almeida P.L., Lourenço N.D., Gaudêncio S.P. 2020. Marine Environmental Plastic Pollution : Mitigation by Microorganism Degradation and Recycling Valorization. Frontiers in Marine Science, 7. https://doi.org/10.3389/fmars.2020.567126

59. Pommier T., Canbäck B., Riemann L., Boström K.H., Simu K., Lundberg P., Tunlid A., Hagström A. 2007. Global patterns of diversity and community structure in marine bacterioplankton. Molecular Ecology, 16, 867-880. https://doi. org/10.1111/j.1365-294X.2006.03189.X

60. Raes E.J., Bodrossy L., Van De Kamp J., Bissett 
A., Ostrowski M., Brown M.V., Sow S.L.S., Sloyan B., Waite A.M. 2018. Oceanographic boundaries constrain microbial diversity gradients in the south pacific ocean. PNAS, 115(35), 8266-8275. https:// doi.org/10.1073/pnas.1719335115

61. Raghul S.S., Bhat S.G., Chandrasekaran M., Francis V., Thachil E.T. 2014. Biodegradation of polyvinyl alcohol-low linear density polyethylene-blended plastic film by consortium of marine benthic vibrios. International Journal of Environmental Science and Technology, 11, 1827-1834. https://doi. org/10.1007/s13762-013-0335-8

62. Rajandas H., Parimannan S., Sathasivam K., Ravichandran M., Su Yin L. 2012. A novel FTIR-ATR spectroscopy based technique for the estimation of low-density polyethylene biodegradation. Polymer Testing, 31(8), 1094-1099. https://doi. org/10.1016/j.polymertesting.2012.07.015

63. Rajeev M., Sushmitha T.J., Toleti S.R., Pandian S.K. 2019. Culture dependent and independent analysis and appraisal of early stage biofilm-forming bacterial community composition in the Southern coastal seawater of India. Science of The Total Environment, 666, 308-320. https://doi.org/10.1016/J. SCITOTENV.2019.02.171

64. Rathore D.S., Sheikh M., Singh S.P. 2021. Marine Actinobacteria: New Horizons in Bioremediation. Environmental and Microbial Biotechnology, December, 425-449. https://doi. org/10.1007/978-981-15-4439-2_20

65. Reisser J., Shaw J., Hallegraeff G., Proietti M., Barnes D.K.A., Thums M., Wilcox C., Hardesty B.D., Pattiaratchi C. 2014. Millimeter-Sized Marine Plastics: A New Pelagic Habitat for Microorganisms and Invertebrates. PLoS ONE, 9(6), e100289. https://doi.org/10.1371/journal.pone.0100289

66. Ren L., Wang G., Huang Y., Guo J., Li C., Jia Y., Chen S., Zhou J.L., Hu H. 2021. Phthalic acid esters degradation by a novel marine bacterial strain Mycolicibacterium phocaicum RL-HY01: Characterization, metabolic pathway and bioaugmentation. Science of The Total Environment, 791, 148303. https://doi. org/10.1016/J.SCITOTENV.2021.148303

67. Renner L.D., Weibel D.B. 2011. Physicochemical regulation of biofilm formation. MRS Bulletin, 36(5), 347-355. https://doi.org/10.1557/mrs.2011.65

68. Roager L., Sonnenschein E.C. 2019. Bacterial Candidates for Colonization and Degradation of Marine Plastic Debris. Environmental Science and Technology, 53(20), 11636-11643. https://doi.org/10.1021/ ACS.EST.9B02212

69. Rummel C.D., Jahnke A., Gorokhova E., Kü D., Schmitt-Jansen M. 2017. Impacts of Biofilm Formation on the Fate and Potential Effects of Microplastic in the Aquatic Environment. https://doi. org/10.1021/acs.estlett.7b00164
70. Ryabushko L., Miroshnichenko E., Blaginina A., Shiroyan A., Lishaev D. 2021. Diatom and cyanobacteria communities on artificial polymer substrates in the Crimean coastal waters of the Black Sea. Marine Pollution Bulletin, 169, 112521. https://doi.org/ https://doi.org/10.1016/j.marpolbul.2021.112521

71. Sangeetha D.R., Ramya R., Kannan K., Robert A.A., Rajesh K.V. 2019. Investigation of biodegradation potentials of high density polyethylene degrading marine bacteria isolated from the coastal regions of Tamil Nadu, India. Marine Pollution Bulletin, 138, 549-560. https://doi.org/10.1016/J. MARPOLBUL.2018.12.001

72. Schlundt C., Mark Welch J.L., Knochel A.M., Zettler E.R., Amaral-Zettler L.A. 2020. Spatial structure in the "Plastisphere": Molecular resources for imaging microscopic communities on plastic marine debris. Molecular Ecology Resources, 20(3), 620-634. https://doi.org/10.1111/1755-0998.13119

73. Sharma M., Dangi P., Choudhary M. 2014. Actinomycetes : Source, Identification, and Their Applications Actinomycetes : Source, Identification, and Their Applications. International Journal of Current Microbiology and Applied Sciences, January 2014.

74. Shivlata L., Satyanarayana T. 2015. Thermophilic and alkaliphilic Actinobacteria: Biology and potential applications. In Frontiers in Microbiology, 6. https://doi.org/10.3389/fmicb.2015.01014

75. Silva M.M., Maldonado G.C., Castro R.O., de Sá Felizardo J., Cardoso R.P., Anjos R.M. dos, Araújo F.V. de. 2019. Dispersal of potentially pathogenic bacteria by plastic debris in Guanabara Bay, RJ, Brazil. Marine Pollution Bulletin, 141, 561-568. https:// doi.org/10.1016/J.MARPOLBUL.2019.02.064

76. Sivan A., Szanto M., Pavlov V. 2006. Biofilm development of the polyethylene-degrading bacterium Rhodococcus ruber. Applied Microbiology and Biotechnology, 72(2), 346-352. https://doi. org/10.1007/s00253-005-0259-4

77. Smith I.L., Stanton T., Law A. 2021. Plastic habitats: Algal biofilms on photic and aphotic plastics. Journal of Hazardous Materials Letters, 2, 100038. https:// doi.org/https://doi.org/10.1016/j.hazl.2021.100038

78. Sung C.C., Tachibana Y., Suzuki M., Hsieh W.C., Kasuya K.I. 2016. Identification of a poly(3-hydroxybutyrate)-degrading bacterium isolated from coastal seawater in Japan as Shewanella sp. Polymer Degradation and Stability, 129, 268-274. https://doi.org/10.1016/J. POLYMDEGRADSTAB.2016.05.008

79. Suzuki M., Tachibana Y., Oba K., Takizawa R., Kasuya K. ichi. 2018. Microbial degradation of poly( $\varepsilon$-caprolactone) in a coastal environment. Polymer Degradation and Stability, 149, 1-8. https://doi.org/10.1016/J. POLYMDEGRADSTAB.2018.01.017 
80. Syakti A.D., Bouhroum R., Hidayati N.V., Koenawan C.J., Boulkamh A., Sulistyo I., Lebarillier S., Akhlus S., Doumenq P., Wong-Wah-Chung P. 2017. Beach macro-litter monitoring and floating microplastic in a coastal area of Indonesia. Marine Pollution Bulletin, 122(1-2), 217-225. https://doi. org/10.1016/j.marpolbul.2017.06.046

81. Syamimi R.I. 2018. Degradation of microplastics by formulated bacterial consortium isolated from mangrove areas in Peninsular Malaysia. In University of Malaya.

82. Syranidou E., Karka K., Amorotti F., Franchini M., Repouskou E., Kaliva M., Vamv M., Kolvenbach B., Fava F., Corvini P.F., Kalogerakis N. 2017. Biodegradation of weathered polystyrene films in seawater microcosms. Scientific Report, 1-12. https:// doi.org/10.1038/s41598-017-18366-y

83. Tosin M., Weber M., Siotto M., Lott C., Innocenti F.D. 2012. Laboratory test methods to determine the degradation of plastics in marine environmental conditions. Frontiers in Microbiology, 3(JUN). https://doi.org/10.3389/fmicb.2012.00225

84. Tseng M., Hoang K.C., Yang M.K., Yang S.F., Chu W.S. 2007. Polyester-degrading thermophilic actinomycetes isolated from different environment in Taiwan. Biodegradation, 18(5), 579-583. https:// doi.org/10.1007/s10532-006-9089-z

85. Valan A.M., Asha K.R.T., Duraipandiyan V., Ignacimuthu S., Agastian P. 2012. Characterization and phylogenetic analysis of novel polyene type antimicrobial metabolite producing actinomycetes from marine sediments: Bay of Bengal India. Asian Pacific Journal of Tropical Biomedicine, 2(10), 803-810. https://doi.org/10.1016/ S2221-1691(12)60233-0

86. Van Cauwenberghe L., Devriese L., Galgani F., Robbens J., Janssen C.R. 2015. Microplastics in sediments: A review of techniques, occurrence and effects. Marine Environmental Research, 111, 5-17. https://doi.org/10.1016/j.marenvres.2015.06.007

87. Walther B.A., Kunz A., Hu C.S. 2018. Type and quantity of coastal debris pollution in Taiwan: A 12-year nationwide assessment using citizen science data. Marine Pollution Bulletin, 135(August), 862-872. https://doi.org/10.1016/j. marpolbul.2018.08.025

88. Woodall Id L.C., Jungblut A.D., Hopkins K., Id A.H., Robinson L.F., Gwinnett C., Paterson G.L.J. 2018. Deep-sea anthropogenic macrodebris harbours rich and diverse communities of bacteria and archaea. PLoS ONE, 13(11), e0206220. https://doi. org/10.1371/journal.pone.0206220

89. Xie H., Chen J., Feng L., He L., Zhou C., Hong P., Sun S., Zhao H., Liang Y., Ren L., Zhang Y., Li C. 2021. Chemotaxis-selective colonization of mangrove rhizosphere microbes on nine different microplastics. Science of The Total Environment, 752, 142223. https://doi.org/10.1016/J. SCITOTENV.2020.142223

90. Yang T., Ren L., Jia Y., Fan S., Wang J., Wang J., Nahurira R., Wang H., Yan Y. 2018. Biodegradation of Di-(2-ethylhexyl) Phthalate by Rhodococcus ruber YC-YT1 in Contaminated Water and Soil. International Journal of Environmental Research and Public Health, 15(5). https://doi.org/10.3390/ IJERPH15050964

91. Zafeiridou M., Hopkinson N.S., Vouvoulis N. 2018. Cigarette smoking: An assessment of tobacco's global environmental footprint across its entire supply chain, and policy strategies to reduce it (1st ed.). World Health Organization (WHO).

92. Zettler E.R., Mincer T.J., Amaral-Zettler L.A. 2013. Life in the "Plastisphere": Microbial Communities on Plastic Marine Debris. Environmental Science \& Technology, 47(13), 7137-7146. https://doi. org/10.1021/es401288x 